\title{
Multilinear approach to the
} precipitation-lightning relationship: a case study of summer local electrical storms in the northern part of Spain during 2002-2009 period

I. Herrero ${ }^{1}$, A. Ezcurra ${ }^{2}$, J. Areitio ${ }^{3}$, J. Diaz-Argandoña ${ }^{4}$, G. Ibarra-Berastegi ${ }^{5}$, and J. Saenz ${ }^{6}$

${ }^{1}$ Dpto. Expresión Gráfica y Proyectos, Universidad del País Vasco UPV-EHU, Escuela Universitaria de Ingeniería Técnica Industrial, 48013-Bilbao, Spain

${ }^{2}$ Dpto. Física Aplicada II, Universidad del País Vasco UPV-EHU, Facultad de Farmacia, 01006-Vitoria, Spain

${ }^{3}$ Research staff of the Meteorological Association of the Basque Country, Amillena, Vitoria, Spain

${ }^{4}$ Dpto. Física Aplicada I, Universidad del País Vasco UPV-EHU, Escuela Universitaria de Ingeniería Técnica Industrial, 01006-Vitoria, Spain

${ }^{5}$ Dpto. Ingenieria Nuclear y Mecánica de Fluídos, Escuela Técnica Superior de Ingeniería, 48013-Bilbao, Spain

Rain-lightning relationships in northern Spain

I. Herrero et al.

Title Page

\section{Abstract}

Introduction

Conclusions

References

Tables Figures

14

- I

4

Back

Close

Printer-friendly Version

Interactive Discussion 
${ }^{6}$ Dpto. Física Aplicada II, Universidad del País Vasco UPV-EHU, Apdo. 644, 4808-Bilbao, Spain

Received: 10 October 2013 - Accepted: 22 October 2013 - Published: 15 November 2013 Correspondence to: I. Herrero (isabel.herrero@ehu.es)

Published by Copernicus Publications on behalf of the European Geosciences Union.

NHESSD

$1,6467-6498,2013$

Rain-lightning relationships in northern Spain

I. Herrero et al.

\begin{tabular}{|c|c|}
\hline \multicolumn{2}{|c|}{ Title Page } \\
\hline Abstract & Introduction \\
\hline Conclusions & References \\
\hline Tables & Figures \\
\hline I4 & \\
\hline Back & \\
\hline Full Screen / Esc \\
\hline Printer-friendly Version \\
\hline Interactive Discussion
\end{tabular}

Interactive Discussion 


\section{Abstract}

Storms developed under local instability conditions are studied in the Spanish Basque region with the aim of establishing precipitation-lightning relationships. Those situations may produce, in some cases, flash flood. Data used correspond to daily rain 5 depth $(\mathrm{mm})$ and the number of CG flashes in the area. Rain and lightning are found to be weakly correlated on a daily basis, a fact that seems related to the existence of opposite gradients in their geographical distribution. Rain anomalies, defined as the difference between observed and estimated rain depth based on CG flashes, are analysed by PCA method. Results show a first EOF explaining $50 \%$ of the variability that structure. Based on those results, a multilinear expression has been developed to estimate the rain accumulated daily in the network based on the CG flashes registered in the area. Moreover, accumulates and maximum values of rain are found to be strongly correlated, therefore making the multilinear expression a useful tool to estimate maximum precipitation during those kind of storms.

\section{Introduction}

The Spanish Basque area is placed in the northern part of the Iberian Peninsula, and forms the south-western corner of the Bay of Biscay. It is a mountainous region divided by a range of $\mathrm{W}-\mathrm{E}$ oriented mountains $1000-1500 \mathrm{~m}$ high that causes the existence of two main basic climatic areas, oceanic in the north and continental in the south. In the northern area, rivers flow into the sea along highly urbanized, narrow and steeped valleys. Under those conditions, the region is particularly vulnerable to flash floods, because of short notice, and high velocities of flooding, particularly when they are produced by intense storms.

25 The main period for storms in the region is from late spring to autumn, mainly produced under local instability. They are usually associated to developing groups of
NHESSD

$1,6467-6498,2013$

Rain-lightning relationships in northern Spain

I. Herrero et al.

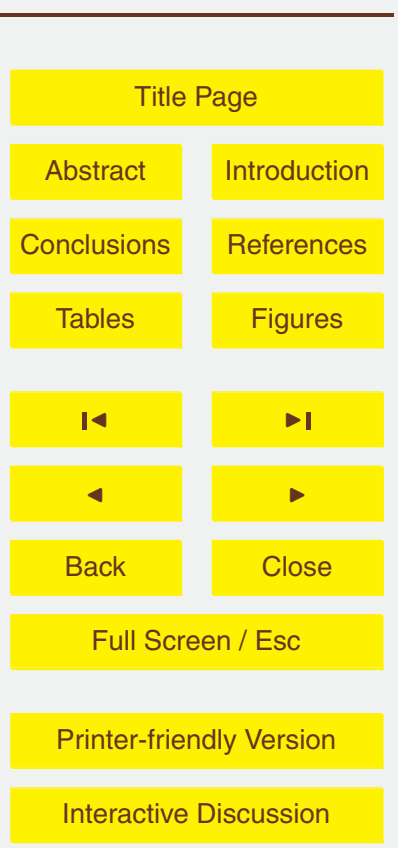


convective cells that move from south-west to north-east, producing rain showers of about $1-2 \mathrm{~h}$ of duration, mostly in the afternoon. However, in some particular situations, the instability produces high rain intensity, particularly in the northern part of the region, causing, in some cases, flash flood. Several examples of this phenomenology can be 5 given, but the more serious event of this type was reported in the 26 August 1983, when rain intensities measured in the area reached maximum values exceeding $110 \mathrm{~mm} \mathrm{~h}^{-1}$ and daily rain depth collected at some locations was about $530 \mathrm{~mm}$. This event caused 39 fatalities and losses of about 1000 millions of euros.

One of the difficulties when dealing with those situations is the gaps in the rain 10 data due to weather station's malfunctions produced by the severe weather conditions. When radar is used, the possibility of electrical failures is not avoided, and there are additional problems, as ground echoes and the conversion of the radar signal to rainfall estimates. For all those reasons, an indirect estimation of rain depth would be of great help for climatological and hydrological applications. In that sense, Soula et al. (1998) proposed that quantitative measurements of lightning activity may provide valuable information for flash-flood analysis and for nowcasting applications.

Regarding this goal, the main issue is to find stable relationships between rain and lightning. However, the correlations between cloud-to-ground (CG) lightning and surface precipitation are highly variable (Rivas et al., 2001), and, as a consequence, a large range of different estimates of precipitation based on lightning are found, with variations of two order of magnitude; for example, Piepgrass et al. (1982) give an average value of rain-yield of $2 \times 10^{4} \mathrm{~m}^{3}$ per CG flash, and Williams et al. (1992) a value of $800 \times 10^{4} \mathrm{~m}^{3}$ per CG flash.

Different studies point out that grouping electrical storm in homogenous class by geographical and seasonal characteristics could be useful in order to find more homogenous rain-yields. Using a large set of data, Williams et al. (1992); Petersen and Rutledge (1998); Rivas et al. (2001) found a seasonal dependence of rain-yields. Also, more recently, Jarayatne and Kuleshov (2006) found significant variations in rain-yields in Australia with geographical location, season and climatic conditions. Similar results
NHESSD

$1,6467-6498,2013$

Rain-lightning relationships in northern Spain

I. Herrero et al.

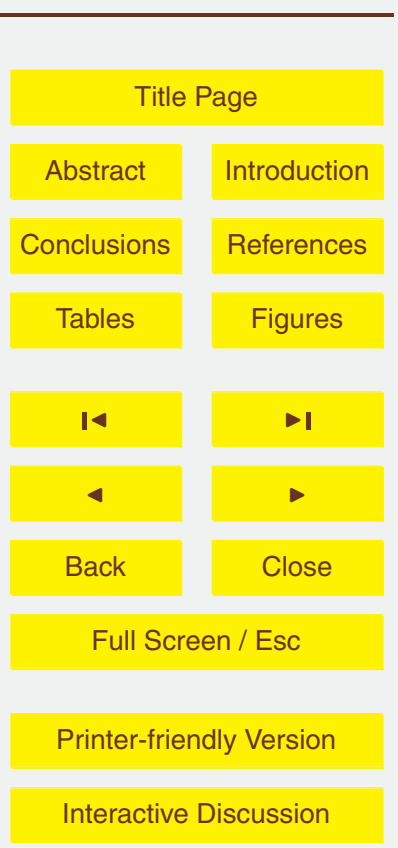


were found by Liou and Kar (2010), who studied $9 \mathrm{yr}$ of data to determine the overall lightning patterns in Taiwan during the summer and winter seasons, using CG-lightning flashes computed in a radius of $10 \mathrm{~km}^{2}$ surrounding each of the 31 rainfall observation stations.

5 Focusing in the Spanish Basque area, the relationship between rainfall and electrical activity has been studied by Ezcurra et al. (2002, 2008). In the first paper authors found an evolution of the rain-yields along the year, and a significant difference when classifying those rain-yields by oceanic and continental events. In the second paper they found that it is possible to discriminate three different meteorological patterns that are linked to the characteristics of electrical events observed in the area, each one associated with different mean rain-yields: (a) Oceanic Advection (NW air fluxes), that appears mostly during winter, with mean rain-yield estimates of about $700 \times 10^{4} \mathrm{~m}^{3}$ per CG flash; (b) Local Instability triggered by surface heating, mostly appearing in summer seasons, with a mean rain-yield of $15 \times 10^{4} \mathrm{~m}^{3}$ per CG flash, and (c) Iberian air fluxes associated with cold air in the upper part of the atmosphere, that are most common in spring and autumn, and with mean rain-yield in the area about $150 \times 10^{4} \mathrm{~m}^{3}$ per CG flash. Results found pointed out that, in this area, different relationships between rain and CG flashes depend on meteorological characteristics of electrical storms and the season in which those storms are produced.

In the work presented here, we will analyse precipitation-lightning relationships during summer storms produced with local instability triggered by surface heating, situations defined by Ezcurra et al. (2008). The spatial variability of these precipitationlightning relationships will be studied using data of 22 meteorological observatories distributed along the region (Fig. 1). Finally, we will make an approach to establish
NHESSD

$1,6467-6498,2013$

Rain-lightning relationships in northern Spain

I. Herrero et al.

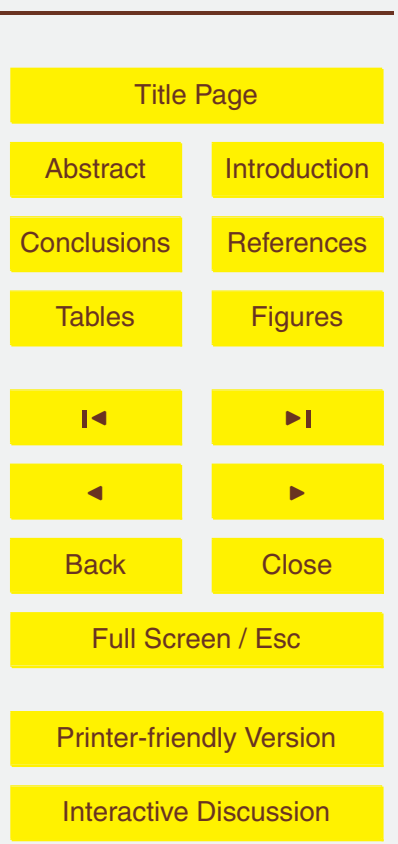




\section{Data and method}

\subsection{Lightning and rain data}

Lightning data used here were obtained by the national meteorological service (AEMET) IMPACT lightning detection system, and correspond to the time and posi5 tion of every individual CG flashes detected during summer local storms during June to August 2002-2009 and located inside the window covering the area of study (about $20800 \mathrm{~km}^{2}$, coordinates $42^{\circ} 24^{\prime} \mathrm{N}-43^{\circ} 36^{\prime} \mathrm{N}$ and $3^{\circ} 36^{\prime} \mathrm{W}-1^{\circ} 24^{\prime} \mathrm{W}$ ). Detection efficiency of IMPACT system typically reaches at least $90 \%$, with an error less than $1 \mathrm{~km}$. We counted the number of CG flashes observed in the whole window every day $(L[d])$, and $(j=1$ to 22$)$, values referred in this paper as $L_{j}[d]$. In order to avoid days when the storms bordered but did not directly affect the region, we selected days with more than 100 CG flashes in the whole area and more than 3 CG flashes around at least one of the observatories, finally keeping 91 days for the study.

15 Rain data were obtained from the automatic network of the Basque regional meteorological service (Euskalmet) and correspond to daily rain gauge accumulates $(\mathrm{mm})$ in the 22 meteorological observatories during the 91 selected days $\left(R_{j}[d]\right.$, being $j=1$ to 22, the observation points).

As already mentioned, we are dealing with a convective phenomena with a typical 20 lifetime of $1-2 \mathrm{~h}$. Therefore, we can assume that daily data are representative of each storm event.

\subsubsection{Method}

In this study daily data of rain and lightning will be compared in order to adjust the linear trend that defines, in general terms, the precipitation-lightning relationship in allow analysing spatial variations of the two variables. We define rain anomalies as

NHESSD

1, 6467-6498, 2013

Rain-lightning relationships in northern Spain

I. Herrero et al.

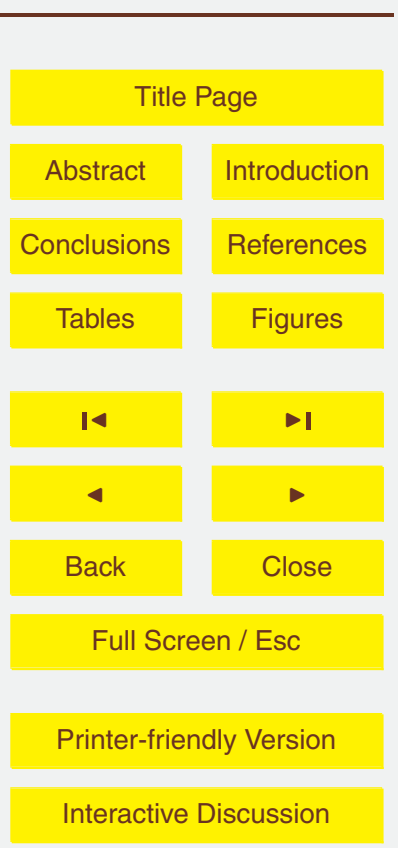


the differences between the actual rain depths measured in every observatory and the linear estimates of rain depths based on CG lightning. The geographical distribution of those rain anomalies will be analysed using PCA (Principal Component Analysis) method. As we work with 22 observational points, we can represent every one of the 591 days of the study by a 22 dimensional vector of anomalies $\left(\Delta_{1}, \Delta_{2}, \Delta_{3}, \ldots, \Delta_{22}\right)[d]$, therefore obtaining a matrix of 91 rows $\times 22$ columns.

The purpose of PCA is to reduce the dimensionality of the sample, but retaining most of the sample information. This transformation is defined in such a way that the first principal component has the largest possible variance. Provided that the explained 10 variability expressed by this first EOF is high enough, we could use the following approach for estimating the vector of daily rain anomalies:

$$
\left(\Delta_{1}, \Delta_{2}, \Delta_{3}, \ldots, \Delta_{22}\right)[d] \simeq \text { PC1 }[d] E O F 1
$$

where, for each day $[d],\left(\boldsymbol{\Delta}_{1}, \boldsymbol{\Delta}_{2}, \boldsymbol{\Delta}_{3}, \ldots, \boldsymbol{\Delta}_{22}\right)[d]$ is the vector of rain anomalies, EOF1 is the first empirical orthogonal function found by the PCA and formed by the so-called 15 rotation coefficients associated to them, and $\mathrm{PC} 1[d]$ is the first principal component associated to the day [ $d$ ], also so-called predictor's value.

From Eq. (1), it can be assumed that daily rain anomalies found in every observatory are almost linearly correlated, which means that the sum of those anomalies can be estimated from the anomaly observed in only one point. In that case, it is possible to 20 postulate that the total rain depth collected in the network every day $(R[d])$ can be estimated based on CG lightning by using the following empirical formula:

$$
R[d]=\alpha R_{j}[d]+\beta L_{j}[d]+\gamma L[d]+\delta
$$

where, for the day $[d], R[d]$ is the sum of rain collected in the 22 observatories, $R_{j}[d]$ is rain collected by one particular $j$ rain gauge observatory, $L_{j}[d]$ is the number of $C G$ 25 lightning flashes observed around the $j$ observatory, and $L[d]$ is the total number of $C G$ flashes observed in the whole area.

\section{NHESSD}

$1,6467-6498,2013$

Rain-lightning relationships in northern Spain

I. Herrero et al.

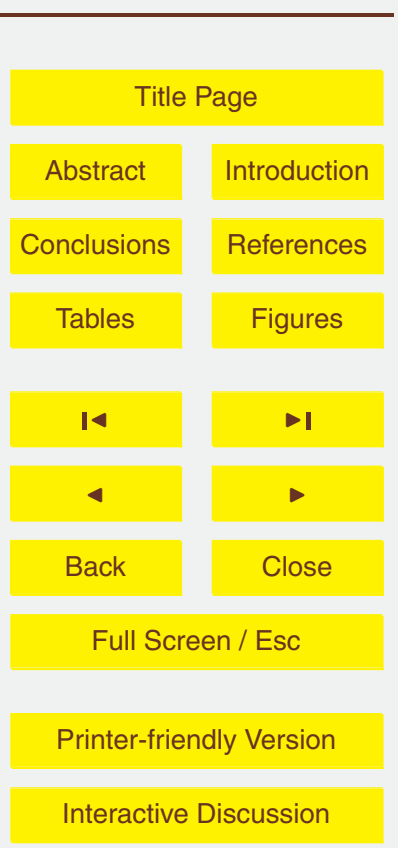


The interpretation of Eq. (2) is very simple. The rain accumulated in the network every day is estimated using the number of CG flashes recorded that day in the whole area $(\gamma L[d])$, and this estimation is then corrected with the rain anomaly observed in a representative point $\left(\alpha R_{j}[d]+\beta L_{j}[d]\right)$. By adding these two terms we expect to esti5 mate rain based on CG lightning taking into account the rain productivity of every particular storm as it is observed. Finally, we have to notice that the term $\delta$ only represents a common offset of rain. The coefficients $\alpha, \beta, \gamma$ and $\delta$ can be deduced empirically from an experimental adjustment, as we will show later in this paper.

It is important to understand that the approach proposed here can be applied only 10

\section{Results and discussion}

\subsection{Characteristics of the lightning-precipitation relationships}

Main statistics of precipitation can be seen in Table 1. Daily mean of rain depths for all the data base is $5 \mathrm{~mm}$ ( $25 \%$ of the observations are equal to zero corresponding to observatories not affected by the storms), but, in the analysed rain episodes, daily means reach the value of $29 \mathrm{~mm}$. On the other hand, daily maximum values range between $1 \mathrm{~mm}$ and $115 \mathrm{~mm}$. Accumulated rain in the 91 days of the study amounts to $9852 \mathrm{~mm}$, and represents about $25 \%$ of total rain collected by the network during summer in the years 2002-2009, but it is essential to keep in mind that the importance of the rain produced by local summer storms lays on their potential risk of producing flash floods in the region because rain is produced in a short time over narrow steeped valleys.

We found that the precipitation accumulated in the network each day is strongly related with the maximum that day $\left(r^{2}=0.8\right)$. Also, the daily accumulated precipitation is correlated with the number of observatories that collect more than a threshold $\tau_{\mathrm{R}}$

NHESSD

$1,6467-6498,2013$

Rain-lightning relationships in northern Spain

I. Herrero et al.

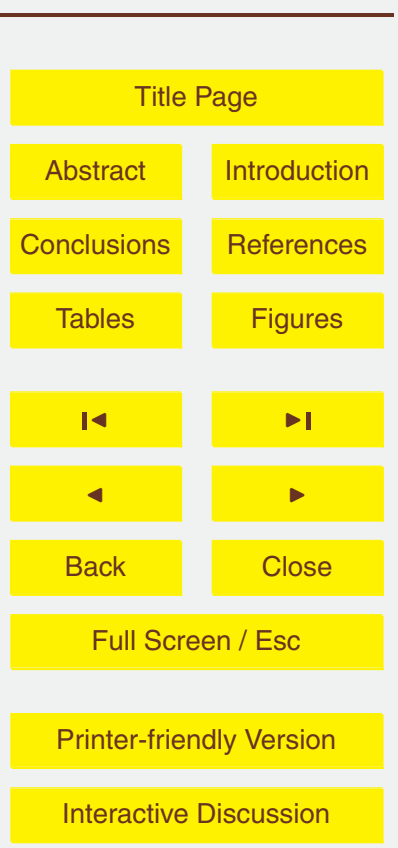


of rain, the significance of this correlation increasing with the threshold value. That is, the extension of the storm activity and the total precipitation that it produces is better correlated when higher rain intensities are reported. The best fit (with $r^{2}=0.84$ ) is found selecting $\tau_{R}=5 \mathrm{~mm}$ (the daily mean rain depth). Similar relationships have also 5 been reported in convective storms by several authors like Byers (1948); Doneaud et al. (1981, 1984); Chèze and Sauvageot (1997); Sauvageot and Mesnard (1999) using radar data.

Statistics of lightning data are also presented in Table 1. Daily mean of the number of CG flashes observed around the observatories is 18, the maximum value being 389 10 and the minimum 0 . In the 91 selected storm days, the total number of CG flashes in the window of study reaches a value of 141874 . In most of the days, the electrical activity is well extended over the area, with $63 \%$ of the days affecting at least two thirds of the rain observatories.

Precipitation and lightning where compared using two spatial scales: (a) considering 15 the whole area, that is, the sum of the precipitation collected in the network against the number of CG flashes in the whole area (Fig. 2a), and (b) considering local relationships, that is, comparing precipitation collected in each rain gauge station against the number of CG flashes that stroked in a radius of $10 \mathrm{~km}$ around them (Fig. 2b). In both graphics we can observe a high dispersion in the data, and we can say that the weak correlation $\left(r^{2}=0.15\right)$ in daily precipitation-lightning relationships is due to the fact that individual cases don't follow the general trend. Observations show that there are situations in which a great number of CG flashes around particular observatories can correspond to low depth of collected precipitation. The opposite is also observed. This fact reflects the difficulties of the problem of estimating, on a daily basis, the rain collected in rain gauge network from CG flashes.

This dispersion is also reflected when the maxima values are used. We compared every day the maximum values of rainfall with the maximum number of CG flashes around each observatory (Fig. 3), obtaining $r^{2}=0.16$. Two points are completely out of the mean trend, corresponding to a dry storm (high lightning activity but little rainfall)
NHESSD

$1,6467-6498,2013$

Rain-lightning relationships in northern Spain

I. Herrero et al.

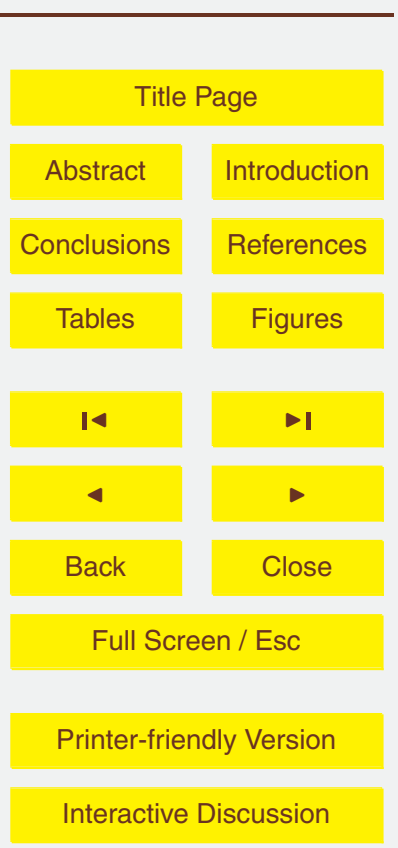


observed in the station 16 situated in the southern part of the area (rightmost point), and to a heavy rain storm (with low number of CG flashes) observed in station 12 situated in the northern part of the area (upmost point).

The observed variability points out to the existence of local conditions that influence 5 the precipitation/lightning ratio. Figure 4a shows mean values of rainfall in each observatory during the period and their isocountour lines. Similarly, Fig. 4b refers to mean values of CG flashes around observatories. Those figures show a clear opposite gradient in the two variables: mean rain depth increases towards the north while mean number of CG flashes decreases in the same direction. The maximum values of rain

PCA analysis of the daily rainfall anomalies, defined in Sect. 2.1.1, gave a first EOF1 that explained $50 \%$ of the variability (Table 2). Two additional EOFs (EOF2 and EOF3) explained respectively 16 and $5 \%$ of data variability.

The first EOF accumulates most of the variability because the studied rainfall anoma20 lies present a well structured spatial and temporal structure. The spatial pattern is reflected in Fig. 5 with the isocontours of the rotation coefficients defining EOF1 in the area of study. In that Fig. 5 we can observe that the higher values of the rotation coefficients are located in the northern part of the area (with values around 0.4 ), while the southern part exhibit smaller values (close to 0.1 ). Therefore, we can say that, on a daily basis, the rain-yield remain almost constant in the southern part of the area, where no big changes are expected due to the low values found in the EOF1. On the contrary, bigger values in EOF1 are found near the coast, pointing out that the rainfall yield has a higher variability in that side of the region. This result is clearly associated
NHESSD

1, 6467-6498, 2013

Rain-lightning relationships in northern Spain

I. Herrero et al.

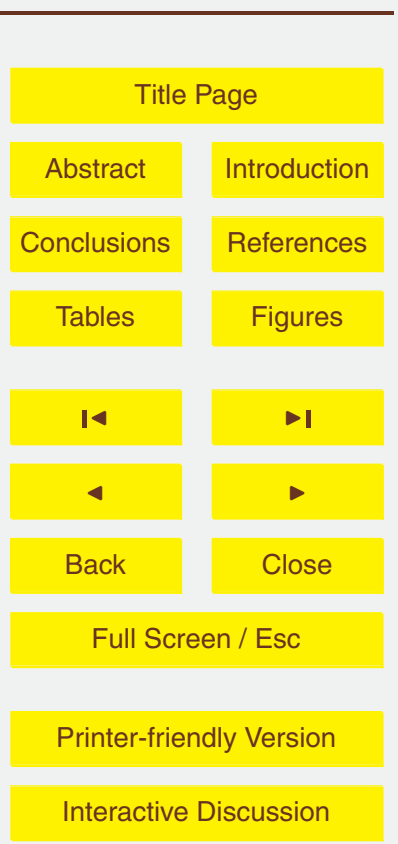


to the fact that the storms that produce higher rainfall with lower lighting activity are observed in the north, near the coast.

Figure 6 shows the frequency distribution of found in our PCA analysis. In this figure we can observe that most of the cases exhibit negative values near to zero, though

5 some of the episodes present positive values that are, in absolute terms, greater that the negative ones. Once again, the interpretation is coherent with observations. Most of the storms are observed in the southern part of the area moving to the north-east. In those episodes, rain is highly localized, and the rain-yields are almost equal to its mean value or even less that the average. This kind of convective storm seems to be more officient producing lightning than rain. In the opposite side, we found a reduced number of storms affecting a wider area, and located in particular in the north, that produce more rain than lightning. The location of the storms and the precipitation efficiency suggest the influence of maritime air in the storm development. Probably, the origin of the observed phenomena is the increase of instability produced by the entrance of very humid maritime air combined with orographic lifting, but further research needs to be done in order to confirm this hypothesis.

\subsection{Multilinear approach}

As already mentioned, we obtained a EOF1 that explains a high part of the variability of the rain anomalies. Consequently, we assume that the sum of rain anomalies observed each day in all the observatories can be linearly estimated from the anomaly observed that day in one particular observatory, and therefore, Eq. (2) can be applied.

In order to verify this last point, for each day and observatory, we calculated the difference between the observed rain and the expected value from CG flashes (adjusting line in Fig. 2b). Then, we added each day all differences in the rain gauge network and 25 we compared that value with the difference observed in every particular observatory, in order to see if the "excess/defect" of precipitation was also reflected in the observatories. We found observatories number 22, 19 and 18 correlated with $r^{2}$ equal to or greater than 0.65 (Fig. 7). Those observatories had the highest values of rotation
NHESSD

1, 6467-6498, 2013

Rain-lightning relationships in northern Spain

I. Herrero et al.

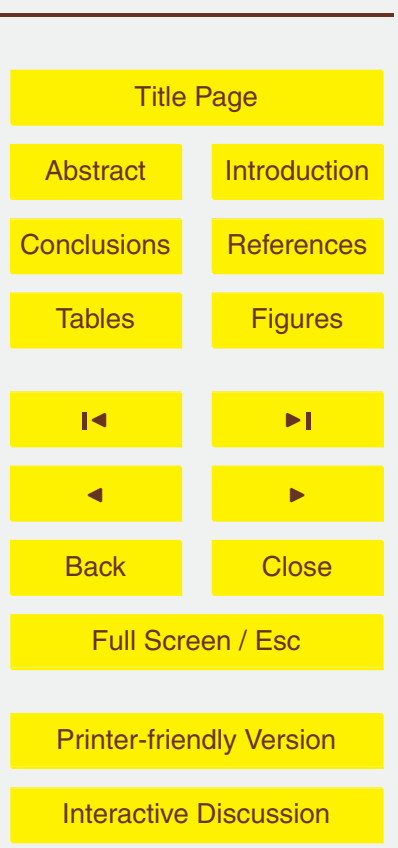


coefficients in the first EOF keeping low values in the rest (Table 2), which is in agreement with PCA theory that also predicts that the variables better defined by each EOF are the ones that present the highest rotation coefficients.

There is another interesting feature in Fig. 7. In most of the days, the sign of the 5 rain anomaly is the same in both axes. This confirms the fact that some observatories are good "representatives" of the precipitation efficiency of the storms every day. Those observatories are located in the northern part, where the highest variability of rain-yield has been detected.

According to those results, we can estimate daily total rain depth using Eq. (2) by 10 selecting the appropriate observatories. In Fig. 8 we compare the observed and es-
timates values of rainfall accumulated in the network every day using observatories
number 22,18 and 19 in Eq. (2), with coefficients $\alpha, \beta, \gamma$ and $\delta$ empirically obtained. All the adjusting lines have slope equal to 1, negligible intercept and $r^{2}$ around 0.8 .

One important problem that could arise in the practical use of Eq. (2) is the possible 15 change of the coefficients $\alpha, \beta, \gamma$ and $\delta$ when the group of data used to empirically deduce those coefficients is different. In order to check this last point, we have calculated those coefficients several times in groups of randomly chosen days, increasing each run the number of days. Table 3 shows and example of this study using the observatory number 22, and presents the coefficients obtained for different groups of days in

a particular run. We can observe in this table that about 75 of the 91 available days are needed to reach nearly constant values in the coefficients, but the root mean square error of estimated total rain depth is more stable and keeps around $54 \mathrm{~mm}$ when at least 55 days are selected $(60 \%)$. Similar results where found in all the runs carried out, also using observatories 18 and 19.

25 When we compare the frequency distribution of both observed and estimated rainfall accumulated in the network (Fig. 9), we observe that, in general, they fit quite well. Better results are achieved when adding data of each year, with differences between observed and estimated rainfall under $20 \%$ in all summers but one, and for the whole period analysed, the difference found is only $156 \mathrm{~mm}$ over $9852 \mathrm{~mm}$. Therefore, it can
NHESSD

1, 6467-6498, 2013

Rain-lightning relationships in northern Spain

I. Herrero et al.

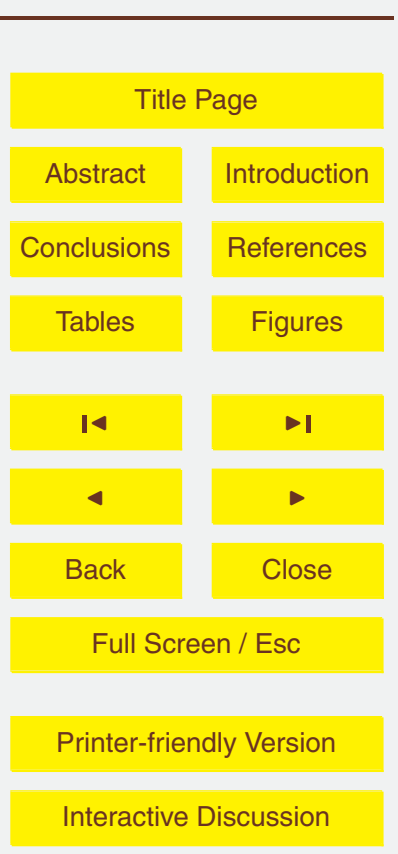


be said that the multilinear expression proposed here reproduces quite well the precipitation collected during summer local electrical storms in the area.

As previously explained, we found that, in the kind of storms were are studying here, the rainfall accumulated in the network is well correlated with the maximum value on 5 a daily basis. As a consequence, we can obtain maximum rain depth expected every day based on estimates of accumulated rainfall. In Fig. 10 we compare observed maximum values with estimated ones based on accumulates from Eq. (2), obtaining $r^{2}=0.8$ with an adjusting line of slope $=1$.

All those results suggest that the phenomena studied here could be interpreted in 10 terms of "precipitation efficiency" of the storms. In a day of storm, the precipitation could be higher or lower than what is expected from the lightning flashes, because the rain-yield of the storms differs depending on the environmental conditions where they develop. This difference is expected to be detected particularly in the observatories where rain-yields changes most, and it seems possible that using these observatories we could estimate rainfall accumulated in an area using lightning data, and, in a second step, the maximum value of rainfall in the area.

\section{Conclusions}

In this work we analyse the precipitation-lightning relationships in 91 summer electrical storms developed under local instability conditions in the Spanish Basque region during summers of 2002-2009. Also, we studied the spatial variability of the lightningprecipitation relationships, using 22 points of observation of the rain gauge network deployed in the area. The characteristics of those relationships allow to develop a new method for estimating daily values of accumulated and maximum rainfall in the network using CG flashes.

25 Main conclusions of this study are:

- Data show a general trend of increasing precipitation with lightning, but individual values corresponding to each day and each location show very different
NHESSD

$1,6467-6498,2013$

Rain-lightning relationships in northern Spain

I. Herrero et al.

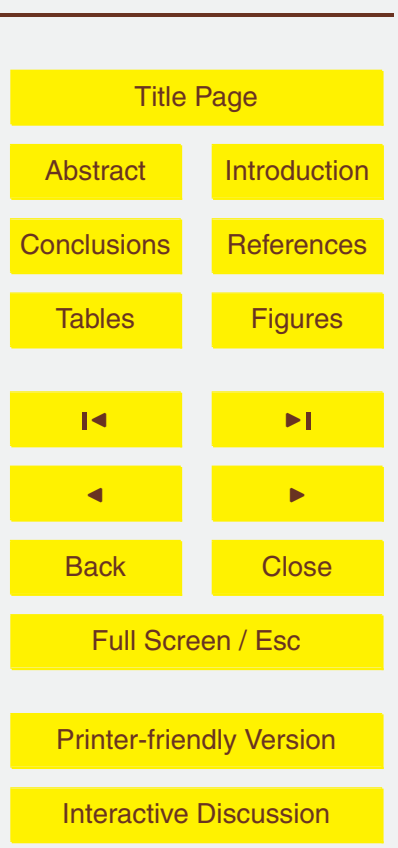


precipitation/lightning ratios. Those ratios seem to have their origin both in the different precipitation efficiency of the storms and also in the local conditions encountered by the storm cells in their trajectory. In that sense, we observed that the geographical distribution of mean rainfall and of mean number of CG flashes show an opposite gradient in the north-south direction, rain increasing towards the north (sea side) and lightning towards the south.

- For each day of the study, we calculated the field of rain anomalies, that is, the differences between actual rainfall depth and the expected value based on lightning in the 22 observatories, that was later analysed by means of PCA method. Results show a first EOF that explains $50 \%$ of the variability, confirming that they are spatially and temporally well structured. We can distinguish two different phenomena that can explain those differences: (a) localized rain produced by small cells moving from south to north-east that produce more lightning than rain, and (b) storms affecting a wider area, located preferably in the northern half of the region that is closer to the sea, and producing more rain than lightning. From this result, we can conclude that objective analysis of lightning and rain data of electrical storms can be used to detect spatial differences of precipitation/lightning ratios under the same meteorological pattern.

- Because the first EOF explains a great part of the variability, it is possible to assume that daily rain anomalies are lineally related. Therefore, we propose to use only one observatory to estimate each day the total anomalous rain depth in the whole network. In our study we found a reduced number of observatories with a high correlation $\left(r^{2} \geq 0.65\right)$ between the rain anomaly they observe and the total anomalous rain depth. Those representative observatories reflect in their daily precipitation variations what we call the "precipitation efficiency" of the storm cells developed under the particular environmental conditions each day. As expected, they are situated in the northern part, close to the sea, where the highest variability of rainfall yields has been detected. Identifying observatories that are well

\section{NHESSD}

1, 6467-6498, 2013

Rain-lightning relationships in northern Spain

I. Herrero et al.

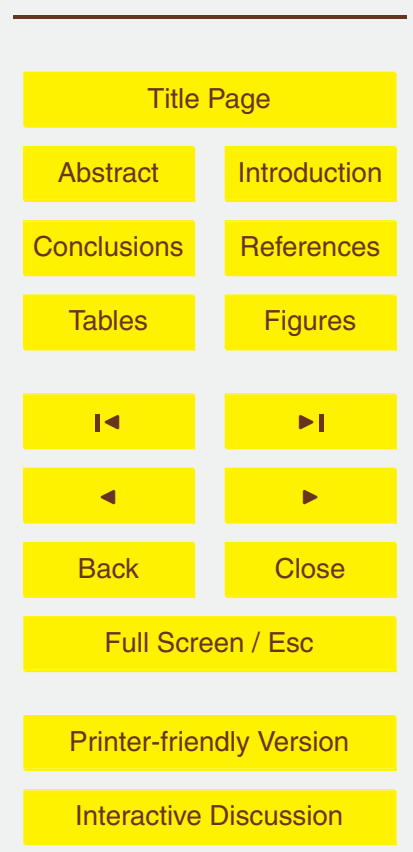


placed to represent different phenomena can be used with the objective of optimizing the use of rain gauge networks.

- All those results allow the use of the an empirical multilinear expression in order to estimate daily rainfall accumulated in the network. In this expression, CG flashes

To end with, we want to remind that the method proposed here is based on the fact that daily rain anomalies are, in our case, lineally correlated, being the linear correlation able to explain about $50 \%$ of the variability of the anomalies during the period studied. Consequently, results have to be taken with caution in order to be applied elsewhere.
NHESSD

$1,6467-6498,2013$

Rain-lightning relationships in northern Spain

I. Herrero et al.

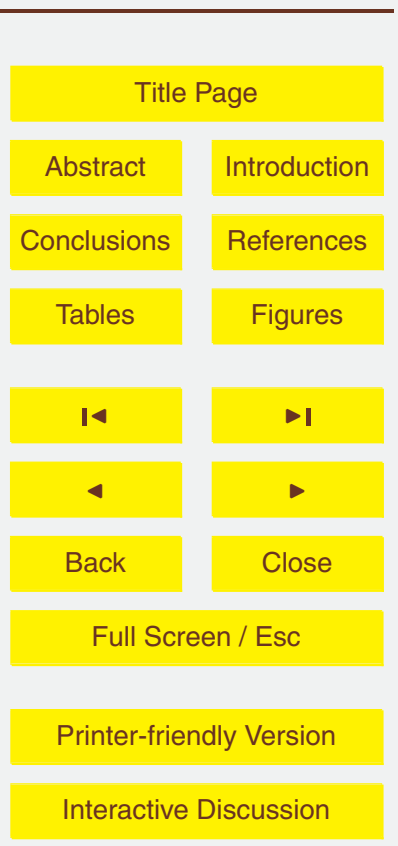




\section{References}

Byers, H. R.: The use of radar in determining the amount of rain falling over a small area, Trans. Amer. Geophys. Union, 29, 187-196, 1948. 6475

Chèze, J. L. and Sauvageot, H.: Area-average rainfall and lightning activity, J. Geophys. Res. 102, 34-44, 1997. 6475

Doneaud, A. A., Smith, P. L., Dennis, A. S., and Sengupta, S.: A simple method for estimating rain volume over an area, Water Resour. Res., 17, 1676-1682, 1981. 6475

Doneaud, A. A., Niscov, S. I., Priegnitz, D. L., and Smith, P. L.: The area-time integral as an indicador for convective rain volumes, J. Climate Appl. Meteor., 23, 555-561, 1984. 6475

10 Ezcurra, A., Areitio, J., and Herrero, I.: Relationship between cloud-to-ground lightning and surface rainfall during 1992-1996 in the Spanish Basque country, Atmos. Res., 61, 239250, 2002. 6471

Ezcurra, A., Saenz, J., Ibarra-Berastegi, G., Areitio, J.: Rainfall yield characteristics of electrical storms observed in the Spanish Basque Country area during the period 1992-1996, Atmos.

15 Res., 89, 233-242, 2008. 6471

Jarayatne, R. and Kuleshov, E.: Geographical and seasonal characteristics of the relationship between lightning ground flash density and rainfall within the continent of Australia, Atmos. Res., 79, 1-14, 2006. 6470

Liou, Y. A. and Kar, S. K.: Study of cloud-to-ground lightning and precipitation and their seasonal and geographical characteristics over Taiwan, Atmos. Res., 95, 115-122, 2010. 6471

Petersen, W. A. and Rutledge, S. A.: On the relationship between cloud-to-ground lightning and convective rainfall, J. Geophys. Res., 103, 14025-14040, 1998. 6470

Piepgrass, M. V., Krider, E. P., and Moore, C. B.: Lightning and surface rainfall during Florida thunderstorms, J. Geophys. Res. 87, 193-201, 1982. 6470

Rivas Soriano, L., De Pablo, F., and García Díez, E.: Relationship between convective precipitation and cloud-to-ground lightning in the Iberian Peninsula, Mon. Weather Rev., 129, 29983003, 2001. 6470

Sauvageot, $\mathrm{H}$. and Mesnard, F.: The relation between the area-average rain rate and the rain cell size distribution parameters, J. Atmos. Sci., 56, 57-70, 1999. 6475

30 Soula, S., Sauvageot, H., Molinié, G., Mesnard, F., Chauzy, S.: The CG lightning activity of storm causing a flashflood, Geophys. Res. Lett. 25, 1181-1184, 1998. 6470
NHESSD

1, 6467-6498, 2013

Rain-lightning relationships in

northern Spain

I. Herrero et al.

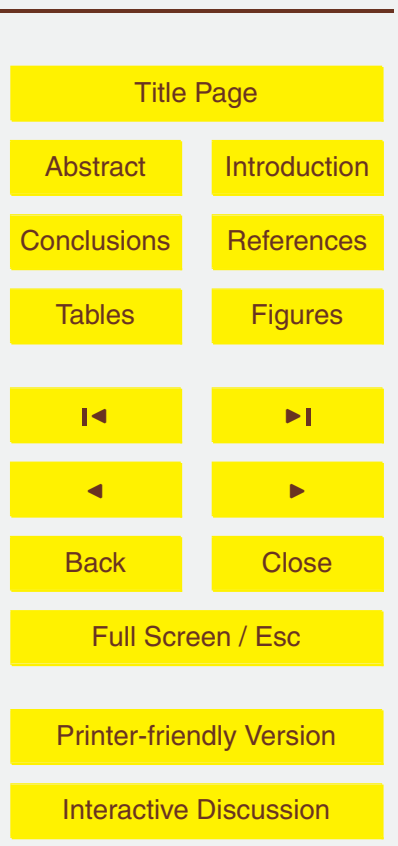


Williams, E. R., Rutledge, S. A., Geotis, S. G., Renno, N., Rasmussen, E., and Rickenbach, T.: A radar and electrical study of tropical "hot towers", J. Atmos. Sci., 49, 1386-1395, 1992. 6470

\section{NHESSD}

$1,6467-6498,2013$

\section{Rain-lightning} relationships in northern Spain

I. Herrero et al.

Title Page

\begin{tabular}{|c|c|}
\hline Abstract & Introduction \\
\hline Conclusions & References \\
\hline Tables & Figures \\
\hline I & \\
\hline & \\
\hline Back & Close \\
\hline Full Screen / Esc
\end{tabular}

Printer-friendly Version

Interactive Discussion 


\section{NHESSD}

$1,6467-6498,2013$

Rain-lightning relationships in northern Spain

I. Herrero et al.

Table 1. Precipitation and lightning statistics for the period of study: daily values of accumulated, mean and maximum rainfall collected in the rain gauge network, number of CG flashes in the whole window of study and around the observatories.

\begin{tabular}{lccc}
\hline Concept & Accumulated & Mean & Maximum \\
\hline Rainfall & $9852(\mathrm{~mm})$ & $5(\mathrm{~mm})$ & $115(\mathrm{~mm})$ \\
CG flashes in the area & 141874 & 1559 & 8343 \\
CG flashes around obs. & - & 18 & 389 \\
\hline
\end{tabular}

Title Page

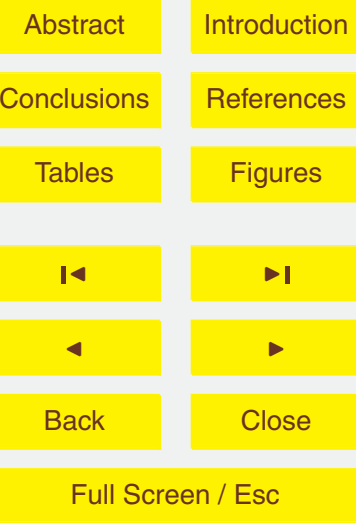

Printer-friendly Version

Interactive Discussion 
Table 2. Rotation coefficients for the first 3 EOFs obtained from PCA analysis of rain anomalies. In brackets, explained variance accumulated in axes.

\begin{tabular}{ccc}
\hline EOF1 $(50 \%)$ & EOF2 $(66 \%)$ & EOF3 $(71 \%)$ \\
\hline 0.29 & -0.17 & 0.14 \\
0.11 & 0.13 & 0.06 \\
0.17 & 0.26 & -0.06 \\
0.13 & 0.19 & 0.00 \\
0.21 & 0.24 & -0.07 \\
0.09 & 0.23 & 0.18 \\
0.23 & 0.01 & -0.58 \\
0.15 & 0.11 & -0.25 \\
0.13 & 0.34 & 0.04 \\
0.14 & 0.28 & -0.06 \\
0.13 & 0.25 & 0.03 \\
0.46 & -0.41 & 0.12 \\
0.09 & 0.10 & -0.11 \\
0.13 & 0.22 & 0.10 \\
0.07 & 0.19 & 0.20 \\
0.08 & 0.25 & 0.54 \\
0.09 & 0.15 & -0.05 \\
0.28 & -0.02 & -0.13 \\
0.23 & 0.01 & -0.27 \\
0.31 & -0.17 & 0.19 \\
0.37 & -0.28 & 0.20 \\
0.24 & 0.08 & -0.05
\end{tabular}

\section{NHESSD}

1, 6467-6498, 2013

Rain-lightning relationships in northern Spain

I. Herrero et al.

Title Page

\section{Abstract \\ Introduction \\ Conclusions \\ References \\ Tables \\ Figures \\ 14 \\ 4 \\ Back \\ Close \\ Full Screen / Esc \\ Printer-friendly Version}

Interactive Discussion 
Table 3. Example of one run to calculate coefficients $\alpha, \beta, \gamma$ and $\delta$ for Eq. (2), using increasing number of randomly chosen days of storm, coefficient of determination $\left(r^{2}\right)$ and root mean square in $\mathrm{mm}$ (RMS).

\begin{tabular}{ccccccc}
\hline N.days & $\alpha$ & $\beta$ & $\gamma$ & $\delta$ & $r^{2}$ & $\mathrm{RMS}(\mathrm{mm})$ \\
\hline 10 & 19.89 & -0.06 & 0.01 & 7.79 & 0.91 & 71.75 \\
15 & 14.70 & -0.35 & -0.01 & 51.57 & 0.96 & 64.47 \\
20 & 14.75 & -0.61 & 0.02 & 12.43 & 0.94 & 54.60 \\
25 & 13.04 & 0.10 & 0.03 & 1.33 & 0.86 & 59.65 \\
30 & 15.50 & -0.38 & 0.00 & 42.60 & 0.89 & 62.19 \\
35 & 16.30 & 0.23 & -0.01 & 31.12 & 0.90 & 66.38 \\
40 & 10.95 & 0.14 & 0.02 & 14.35 & 0.75 & 61.24 \\
45 & 14.61 & -0.74 & 0.02 & 10.10 & 0.84 & 53.88 \\
50 & 13.16 & -0.46 & 0.01 & 28.00 & 0.76 & 57.48 \\
55 & 12.89 & -0.46 & 0.02 & 10.34 & 0.68 & 54.98 \\
60 & 13.68 & -0.68 & 0.02 & 17.59 & 0.83 & 54.60 \\
65 & 14.72 & -0.96 & 0.03 & 10.35 & 0.80 & 54.64 \\
70 & 14.18 & -0.38 & 0.01 & 17.15 & 0.84 & 54.73 \\
75 & 14.19 & -0.63 & 0.02 & 14.62 & 0.82 & 53.77 \\
80 & 14.17 & -0.49 & 0.02 & 18.90 & 0.83 & 53.88 \\
85 & 14.25 & -0.39 & 0.02 & 11.70 & 0.78 & 53.73 \\
90 & 14.48 & -0.58 & 0.02 & 14.39 & 0.82 & 53.49 \\
\hline
\end{tabular}

Rain-lightning relationships in northern Spain

I. Herrero et al.

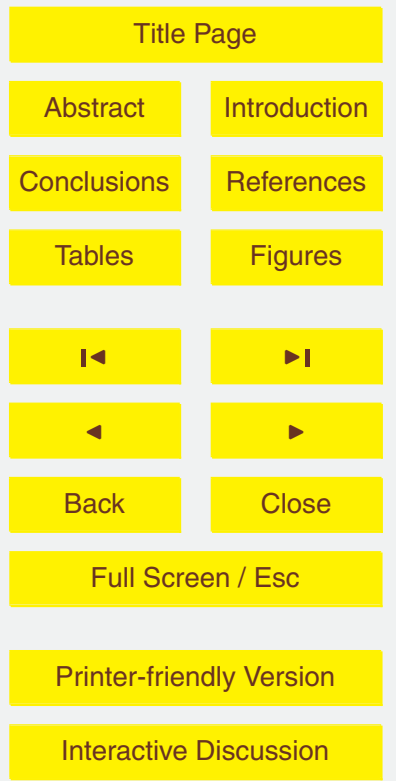



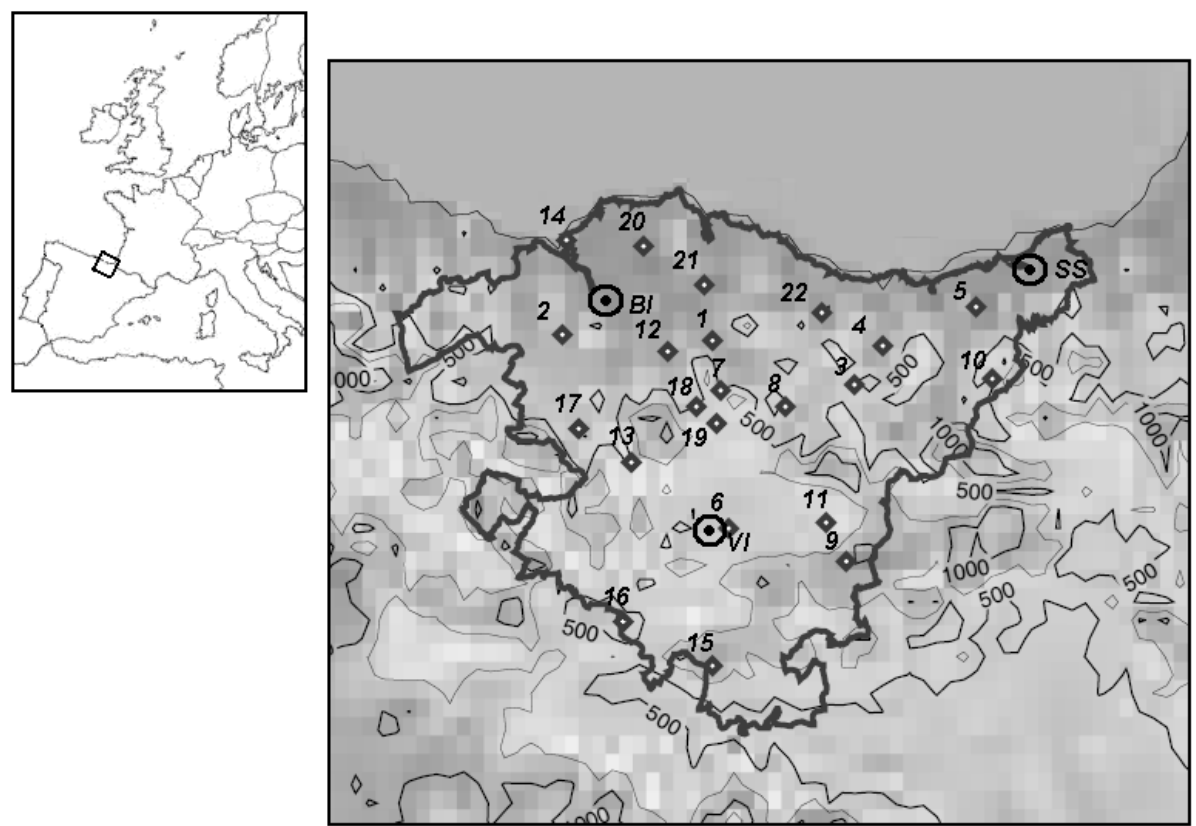

Fig. 1. Spanish Basque country area location in Europe. In zoom, the distribution of the 22 observatories of the study and of the main cities (BI: Bilbao, SS: San Sebastian, VI: Vitoria).

\section{NHESSD}

$1,6467-6498,2013$

Rain-lightning relationships in northern Spain

I. Herrero et al.

Title Page

\begin{tabular}{|c|c|}
\hline Abstract & Introduction \\
\hline Conclusions & References \\
\hline Tables & Figures \\
\hline I4 & \\
\hline & \\
\hline Back & Close \\
\hline Full Screen / Esc \\
\hline
\end{tabular}

Printer-friendly Version

Interactive Discussion 


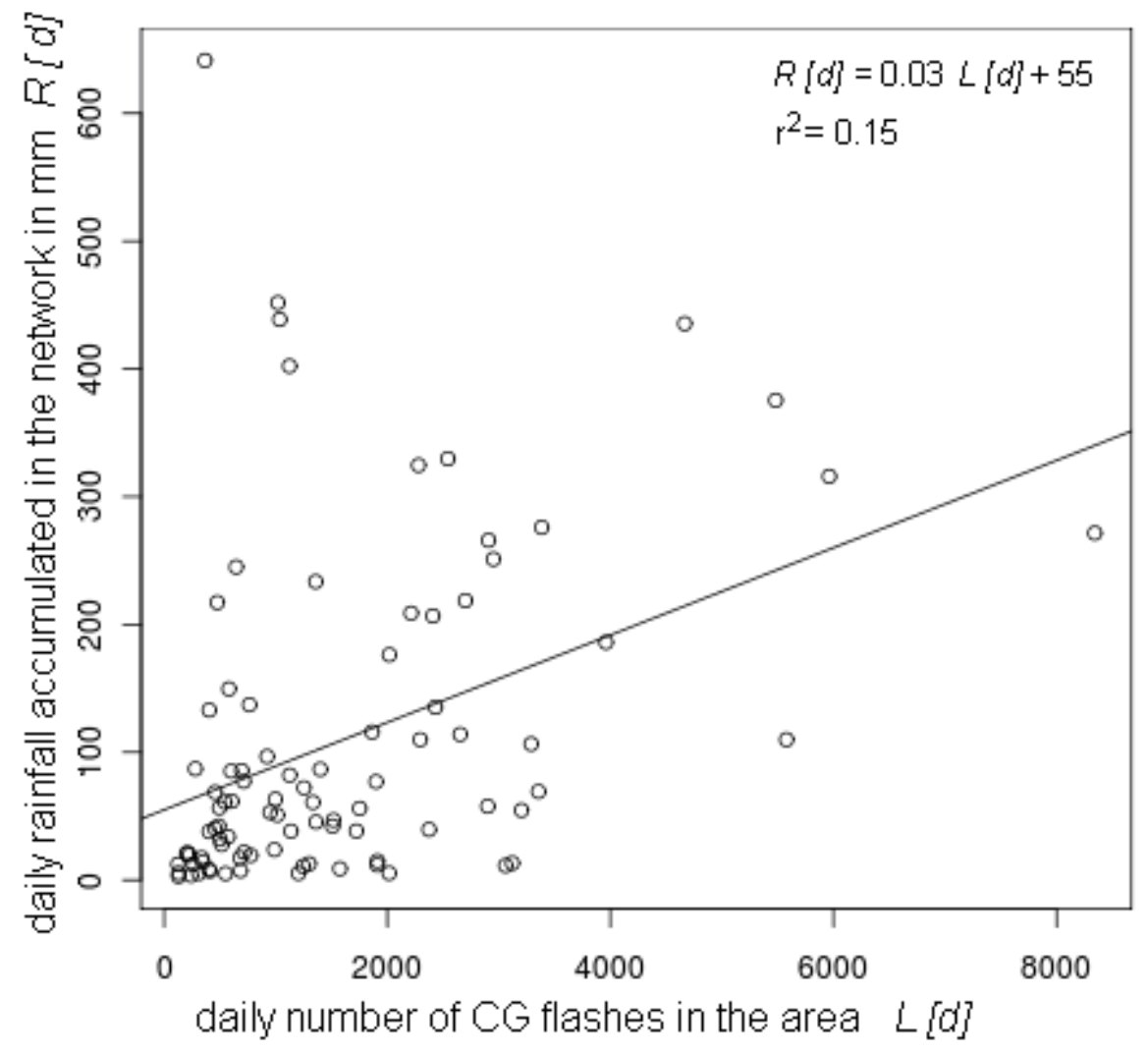

NHESSD

$1,6467-6498,2013$

Rain-lightning relationships in northern Spain

I. Herrero et al.

Title Page

\begin{tabular}{|c|c|}
\hline Abstract & Introduction \\
\hline Conclusions & References \\
\hline Tables & Figures \\
\hline I4 & \\
\hline & \\
\hline Back & Close \\
\hline Full Screen / Esc \\
\hline
\end{tabular}

Printer-friendly Version

Fig. 2a. Daily precipitation-lightning relationships with data of the whole area.

Interactive Discussion 


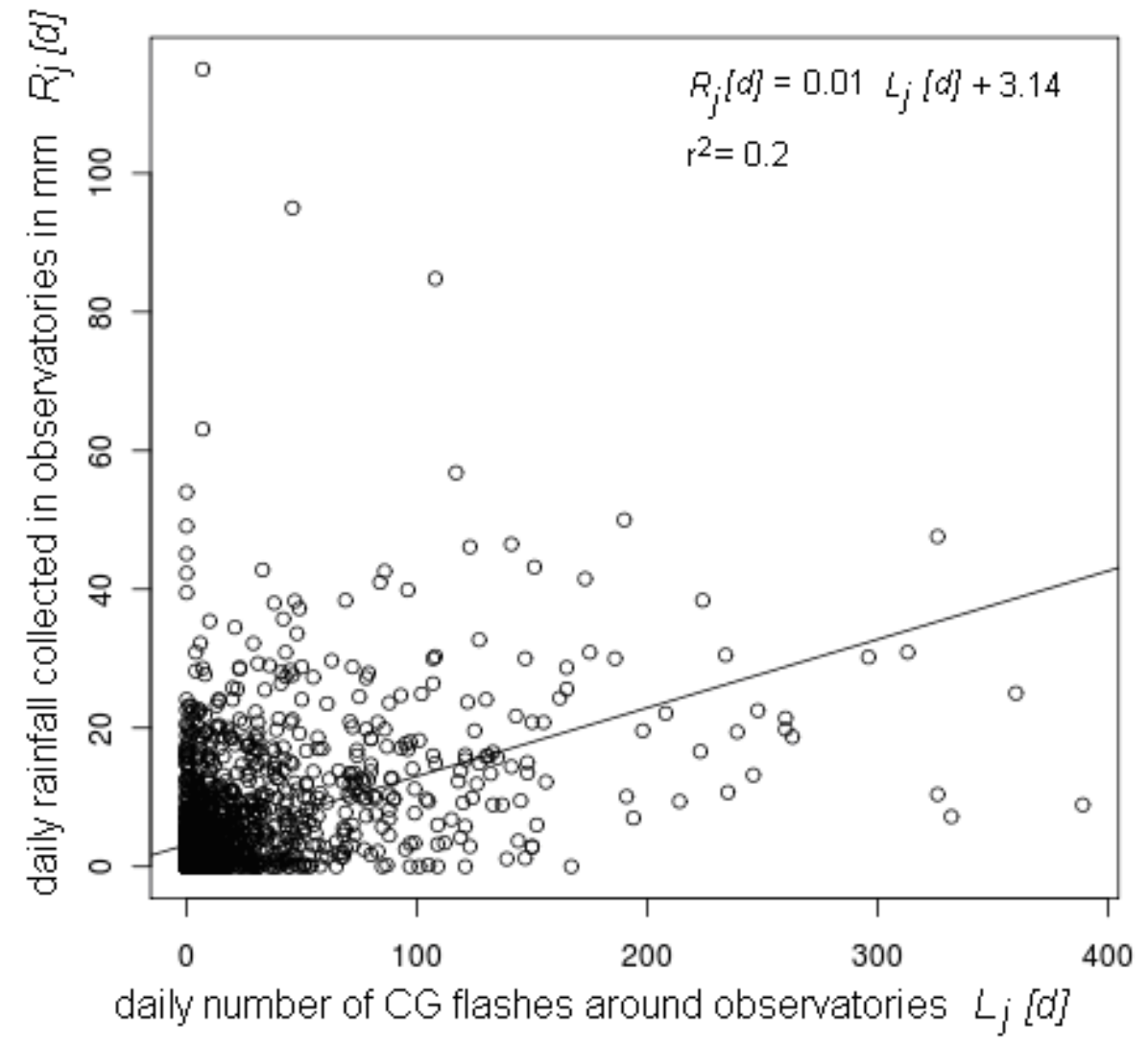

Fig. 2b. Daily precipitation-lightning relationships with data corresponding to each observatory.

\section{NHESSD}

1, 6467-6498, 2013

Rain-lightning relationships in northern Spain

I. Herrero et al.

Title Page

\begin{tabular}{|c|c|}
\hline Abstract & Introduction \\
\hline Conclusions & References \\
\hline Tables & Figures \\
\hline I4 & \\
\hline & \\
\hline Back & Close \\
\hline Full Screen / Esc \\
\hline
\end{tabular}

Printer-friendly Version

Interactive Discussion 


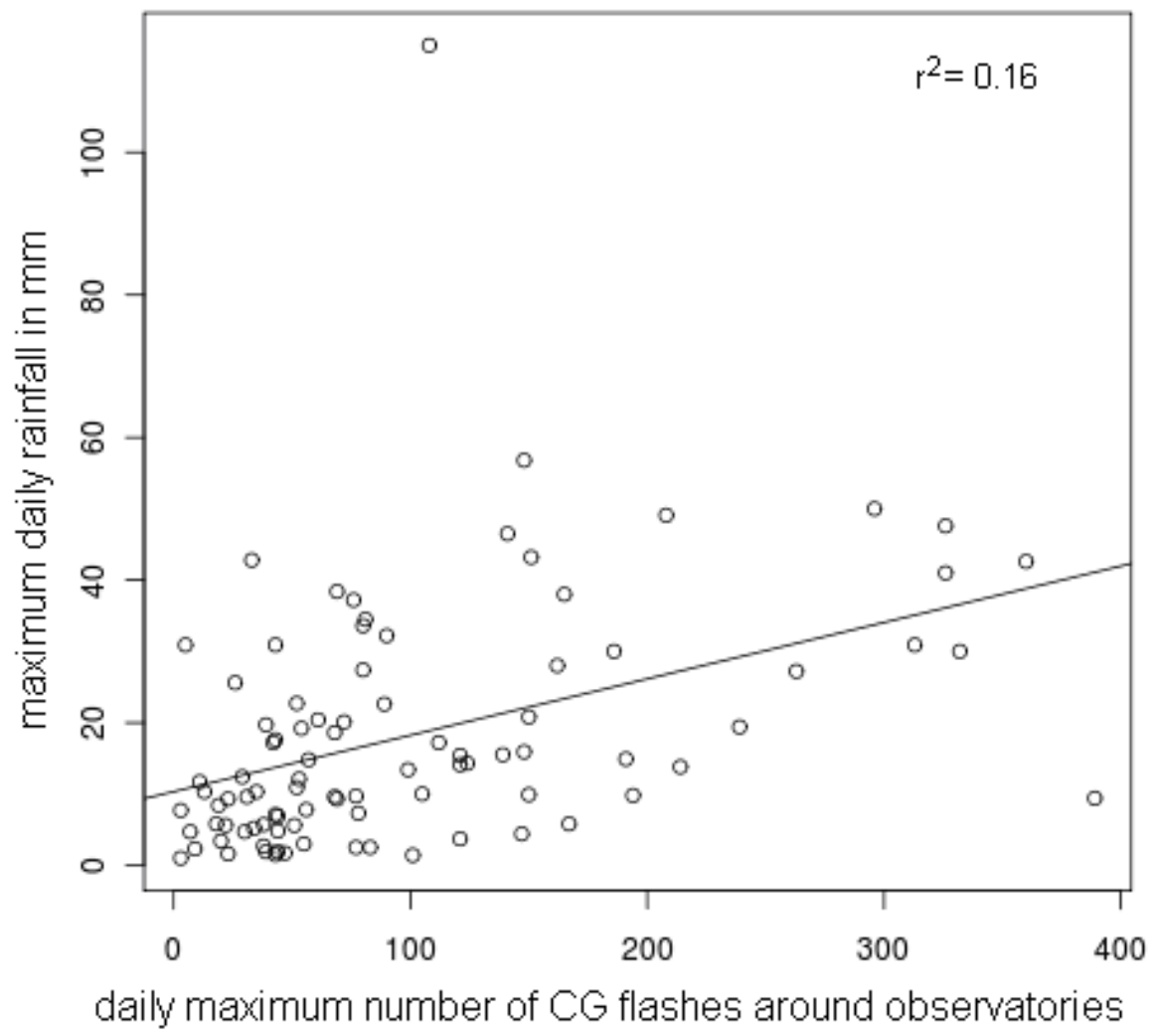

NHESSD

$1,6467-6498,2013$

Rain-lightning relationships in northern Spain

I. Herrero et al.

Title Page

\begin{tabular}{|c|c|}
\hline Abstract & Introduction \\
\hline Conclusions & References \\
\hline Tables & Figures \\
\hline I & \\
\hline & \\
\hline Back & Close \\
\hline Full Screen / Esc \\
\hline
\end{tabular}

Fig. 3. Maximum number of CG flashes around the observatories vs. maximum rainfall in $\mathrm{mm}$ for each day of the study.

Printer-friendly Version

Interactive Discussion 


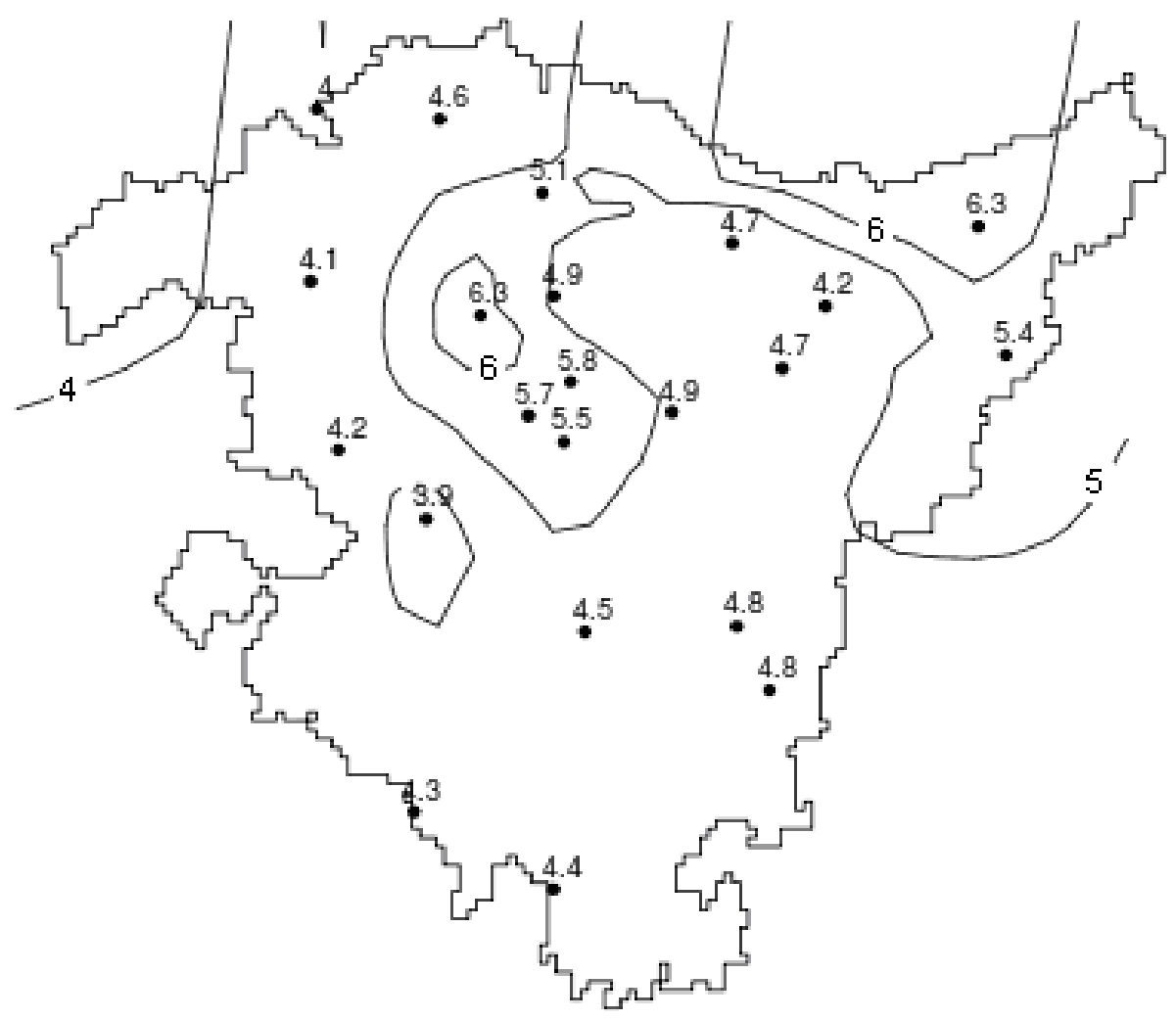

Fig. 4a. Spatial distribution of the mean daily rainfall in $\mathrm{mm}$ : isolines and corresponding value in each observatory.

\section{NHESSD}

$1,6467-6498,2013$

Rain-lightning relationships in northern Spain

I. Herrero et al.

Title Page

\begin{tabular}{c|c} 
Abstract & Introduction \\
\hline Conclusions & References \\
\hline Tables & Figures \\
\hline 14 & \\
\hline Back & Close \\
\hline Full Screen / Esc
\end{tabular}

Printer-friendly Version

Interactive Discussion 


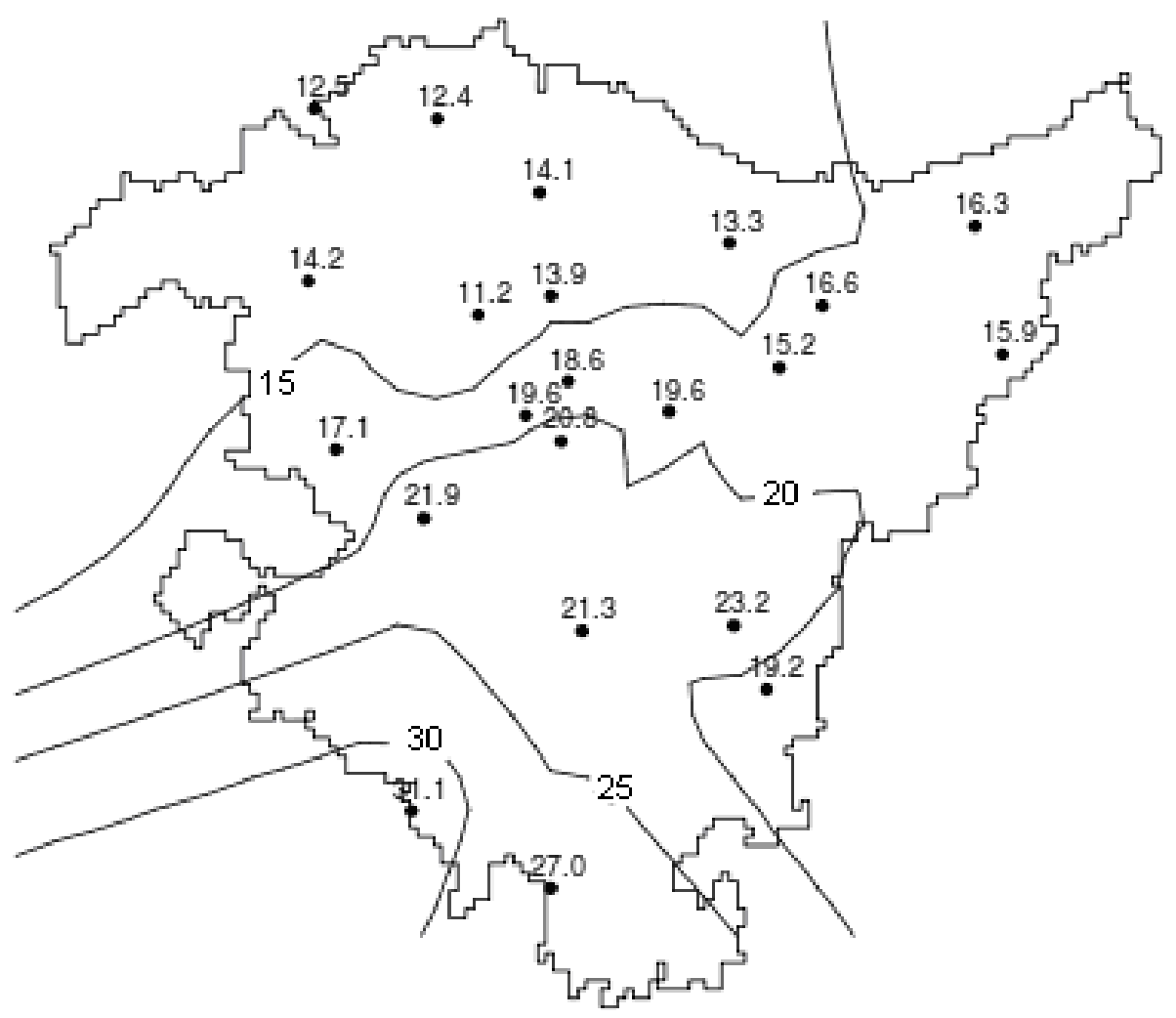

Fig. 4b. Spatial distribution of the mean daily number of CG counts around observatories: isolines and corresponding value in each observatory.

\section{NHESSD}

$1,6467-6498,2013$

Rain-lightning relationships in northern Spain

I. Herrero et al.

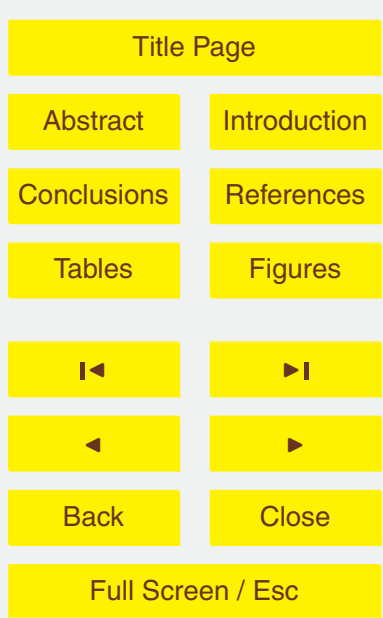

Printer-friendly Version

Interactive Discussion 


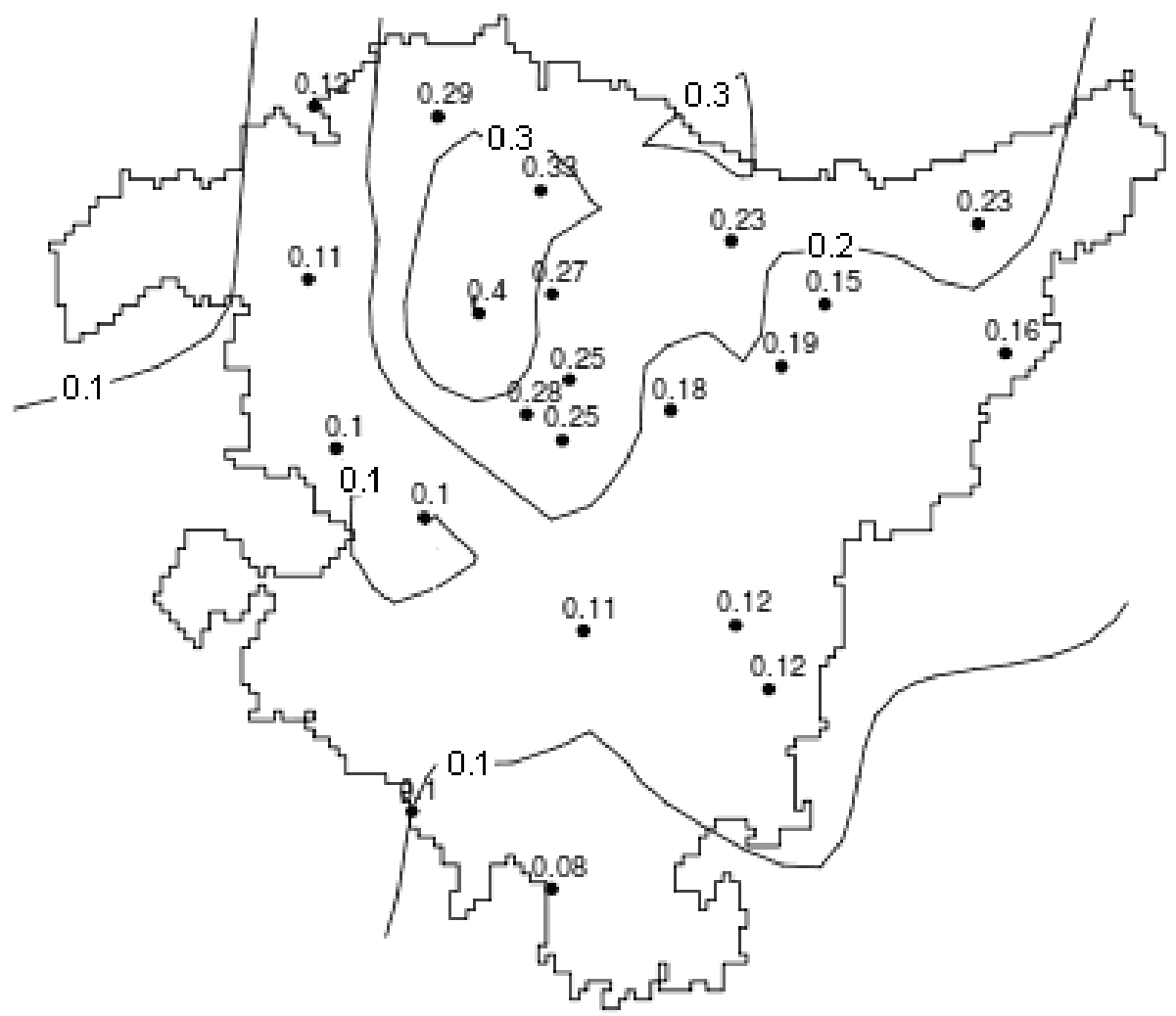

Fig. 5. Spatial distribution of: isolines and corresponding value in each observatory.

\section{NHESSD}

1, 6467-6498, 2013

Rain-lightning relationships in northern Spain

I. Herrero et al.

Title Page

\begin{tabular}{c|c} 
Abstract & Introduction \\
Conclusions & References \\
\hline Tables & Figures \\
\hline I4 & \\
\hline Back & Close \\
\hline Full Screen / Esc
\end{tabular}

Printer-friendly Version

Interactive Discussion 


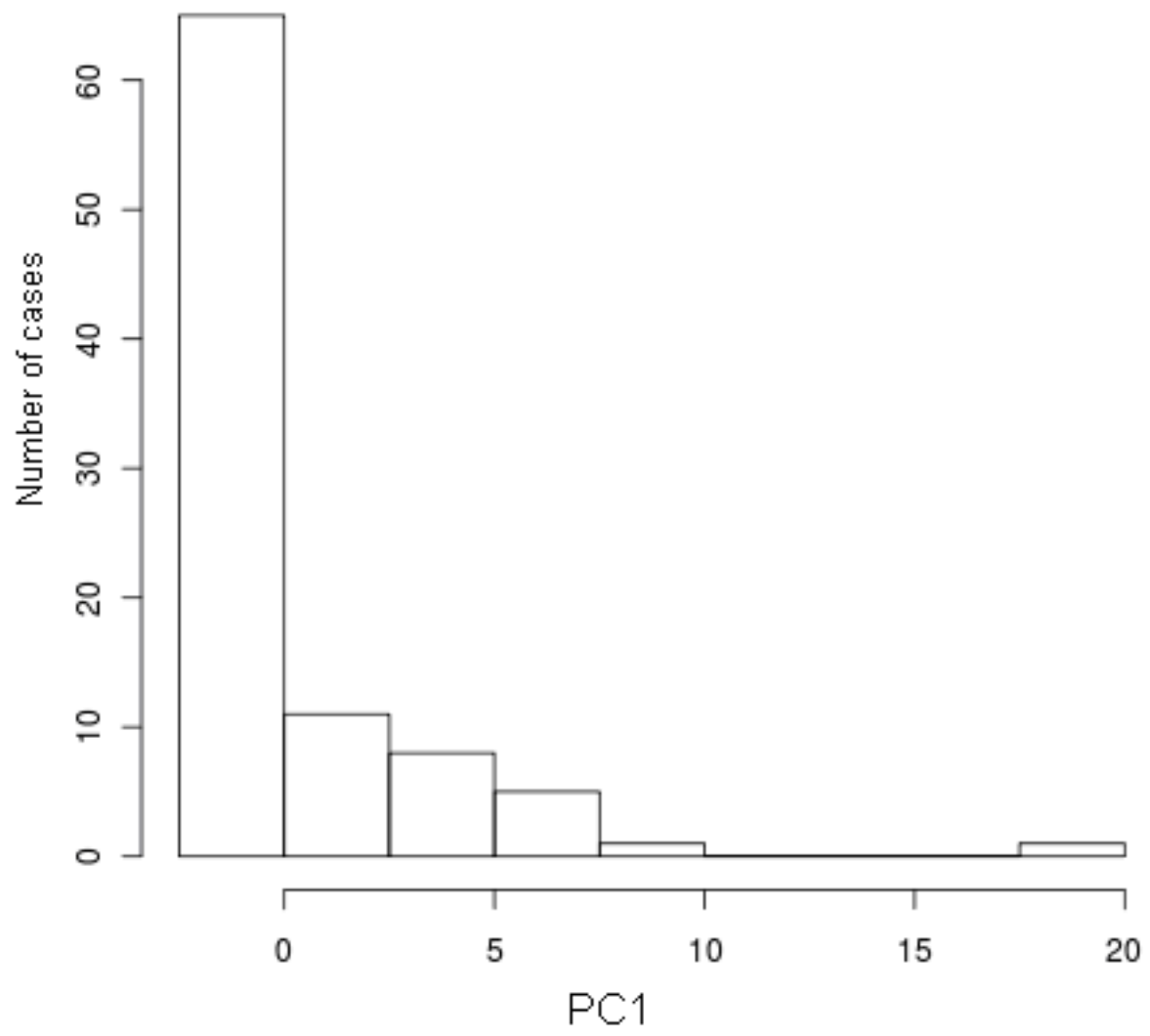

NHESSD

1, 6467-6498, 2013

Rain-lightning relationships in northern Spain

I. Herrero et al.

Title Page

\begin{tabular}{c|c} 
Abstract & Introduction \\
\hline Conclusions & References \\
\hline Tables & Figures \\
\hline Back & Close \\
\hline Full Screen / Esc \\
\hline Printer-friendly Version
\end{tabular}

Interactive Discussion

Fig. 6. Frequency distribution of PC1 coefficients. 

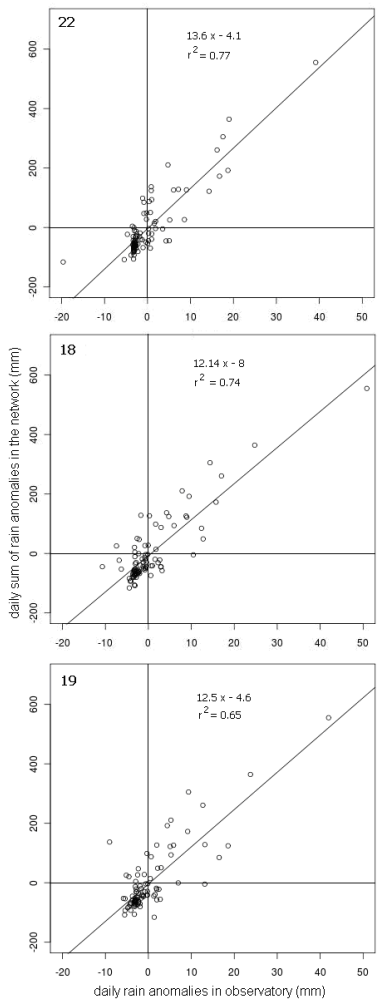

NHESSD

$1,6467-6498,2013$

Rain-lightning relationships in northern Spain

I. Herrero et al.

Title Page

\begin{tabular}{c|c} 
Abstract & Introduction \\
\hline Conclusions & References \\
\hline Tables & Figures \\
\hline 14 & \\
\hline Back & Close \\
\hline Full Screen / Esc
\end{tabular}

Fig. 7. Anomalies in individual observatory (number 22, 18 and 19 from top to bottom) vs. sum of anomalies in the network for each day of the study.

Printer-friendly Version

Interactive Discussion 


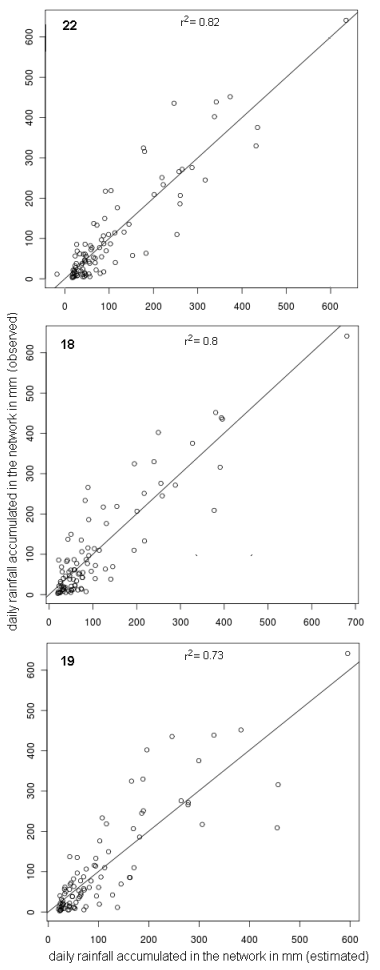

\section{NHESSD}

$1,6467-6498,2013$

Rain-lightning relationships in northern Spain

I. Herrero et al.

Title Page

\begin{tabular}{|c|c|}
\hline Abstract & Introduction \\
\hline Conclusions & References \\
\hline Tables & Figures \\
\hline I & \\
\hline 4 & $-\mathbf{I}$ \\
\hline Back & Close \\
\hline Full Screen / Esc
\end{tabular}

Fig. 8. Daily total rainfall in the network $(\mathrm{mm})$, estimated vs. observed. Estimated based on Eq. (2) with observatories number 22, 18 and 19 (from top to bottom). All adjusting lines have slope $=1$ and negligible intercept. 


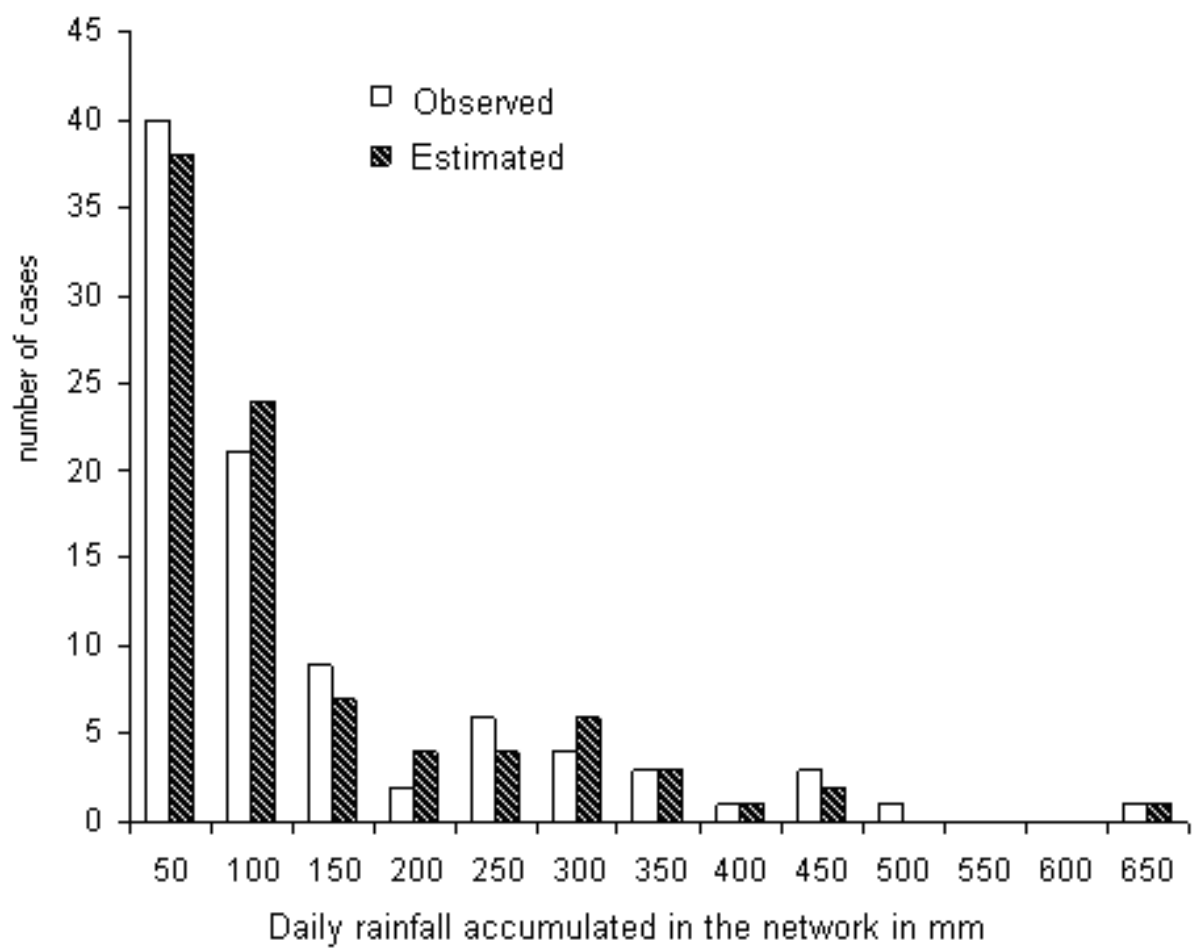

Fig. 9. Frequency distribution of observed and estimated daily rain depth accumulated in the network (mm).

\section{NHESSD}

1, 6467-6498, 2013

Rain-lightning relationships in northern Spain

I. Herrero et al.

Title Page

\begin{tabular}{|c|c|}
\hline Abstract & Introduction \\
\hline Conclusions & References \\
\hline Tables & Figures \\
\hline $\mathbf{1}$ & \multicolumn{1}{|c|}{$\mid$} \\
\hline 4 & \\
\hline Back & Close \\
\hline Full Screen / Esc
\end{tabular}

Printer-friendly Version

Interactive Discussion 


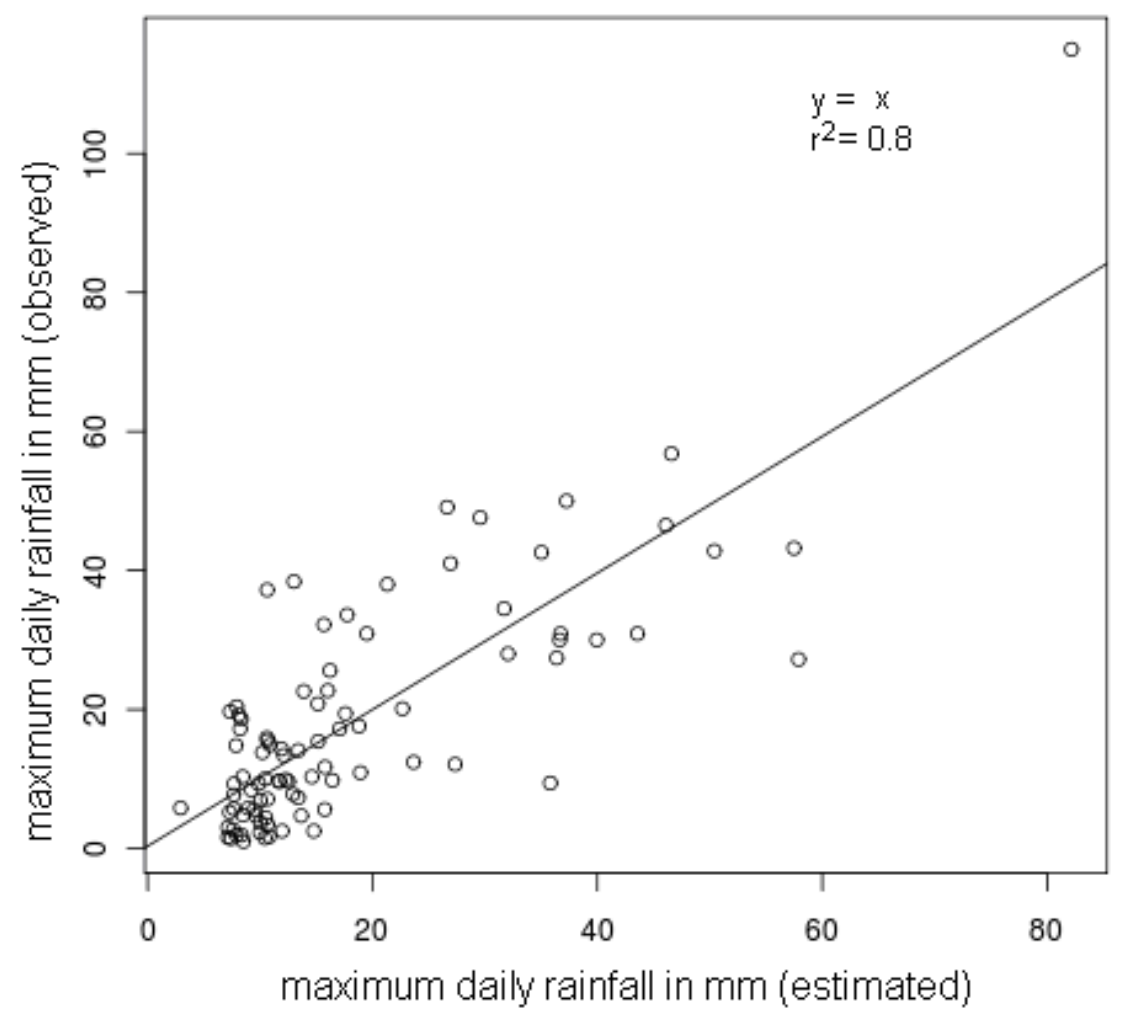

Fig. 10. Maximum daily rainfall $(\mathrm{mm})$, estimated vs. observed. Estimation was based on accumulates from Eq. (2).

\section{NHESSD}

1, 6467-6498, 2013

Rain-lightning relationships in northern Spain

I. Herrero et al.

Title Page

\begin{tabular}{|c|c|}
\hline Abstract & Introduction \\
\hline Conclusions & References \\
\hline Tables & Figures \\
\hline I & \\
\hline & \\
\hline Back & Close \\
\hline Full Screen / Esc
\end{tabular}

Printer-friendly Version

Interactive Discussion 